\title{
Technical Efficiency and Technology Gap Ratio in Cocoa Production in Nigeria: A Stochastic Metafrontier-Tobit (Sm-Tobit) Approach
}

\author{
Aminu, F. O. ${ }^{1^{*}}$ Ayinde, I. A. ${ }^{2}$ \\ 1. Department of Agricultural Technology, School of Technology, Yaba College of Technology, Epe Campus, Yaba, \\ Lagos State, Nigeria \\ 2. Department of Agricultural Economics and Farm Management, Federal University of Agriculture, Abeokuta, \\ Nigeria
}

\section{ARTICLE INFO}

Article history

Received: 15 May 2021

Accepted: 1 June 2021

Published Online: 31 July 2021

\section{Keywords: \\ Cocoa farmers \\ Metafrontier \\ Technical efficiency \\ Technology gap \\ Nigeria}

\begin{abstract}
The study analysed the technical efficiency and technology gap ratio in cocoa production in Nigeria. A multistage sampling technique was used to select 390 cocoa farmers from three zones where cocoa is commercially grown in Nigeria. Separate stochastic frontier models were estimated for farmers in Kwara, Edo and Ondo States, along with a metafrontier model to obtain alternative estimates for the technical efficiencies of farmers in the different states. Subsequently, a Tobit model was used to access the factors influencing cocoa production in the study area. Results revealed that, the average technical efficiency level was 0.685 for the pooled sample, 0.506 , 0.837 and 0.713 for Kwara, Edo and Ondo States respectively, suggesting that there is substantial scope to improve cocoa production in Nigeria. The mean MTR values of $0.506,0.837$ and 0.712 for Kwara, Edo and Ondo States respectively, implied that Edo State was more technically efficient than other states in the study area. The mean technology gap ratio (TGR) value of $84.3 \%$ indicated that, on the average, the cocoa farmers in the study areas would have to close a gap of about $15.7 \%$ in order for them to be technically efficient. The study recommended that cocoa farmers in Edo and Ondo States could improve their technical efficiency through a better management using the available technologies and resources while intervention to raise technology that will help close the gap between the regional frontier curve and the global frontier curve through raising and distributing disease resistant and high yielding cocoa seedlings to the farmers should be adopted in Kwara State.
\end{abstract}

\section{Introduction}

The contribution of cocoa to Nigeria economy in the past cannot be easily overlooked. Cocoa was first cultivated in the western region of Nigeria in 1890. It was the most important agricultural export crop in Nigeria during the $1950 \mathrm{~s}$ and $1960 \mathrm{~s}$. Its cultivation gained prominence rapidly in Nigeria such that by 1965 , Nigeria became the second largest producer in the world (Adegeye, 1998) Cocoa was the main agricultural stake of Nigeria economy until 1970's when the crude oil was discovered in the country in commercial quantity and Nigeria is now the world's fourth largest producer of Cocoa, after Ivory Coast, Indonesia and Ghana, and the third largest exporter, after Ivory Coast and Ghana (Becvarova and Verter, 2014). Cocoa is the single agricultural export commodity

*Corresponding Author:

Aminu, F. O.

Department of Agricultural Technology, School of Technology, Yaba College of Technology, Epe Campus, Yaba, Lagos State, Nigeria; Email:folaafe02@gmail.com 
that has earned foreign exchange more than other crops, offers employment to many people, both directly and indirectly, and serves as an important source of raw materials, and source of revenue to governments of cocoa producing states (Folayan et al., 2006). In 2007 and 2008, agricultural production contributed $41.9 \%$ and $37.8 \%$ to non-oil export out of which cocoa contributed $12.5 \%$ and $13.9 \%$ respectively (CBN, 2009). Cocoa is a high value cash crop among farmers in the major producing areas in Nigeria. In total, more than 20 million people depend directly on cocoa for their livelihood. Approximately, $90 \%$ of the productions are exported in the form of beans or semi-manufactured cocoa products (Taphee et al., 2015).

In spite of the significance of cocoa to Nigerian economy, its production in Nigeria has witnessed a downward trend after 1971 season, when its export declined to 216,000 metric tons in 1976 , and 150,000 metric tons in 1986 , therefore reducing the country's market share to about $6 \%$ and to fourth largest producer to date. In 2010, Cocoa production accounted for only $0.3 \%$ of agricultural GDP. The decline in production according to Oluyole and Usman (2006) Folayan et al., (2006) and Cadoni (2013) could be attributed to the following causes; advent of the petroleum sector which led to the neglect of agriculture; policies and activities of the Nigerian Cocoa Marketing Board (NCMB) of 1978-1986; non-availability and high cost of cocoa production input; activities of middlemen; over- aged and low yielding trees, non-remunerative prices; non-availability of farm labour; old agronomic practices, poor fertility status of cultivated land; and lack of credit to cocoa farmers. Other factors are incidence of pests and diseases, use of fake and substandard agrochemicals, use of poor planting materials, poor handling of post-harvest processes and inefficient agricultural extension services which have resulted in inefficiencies that repress the development of cocoa production in the country.

One of the major objectives of the cocoa farmers is to increase production on a sustainable basis at the farm level. Management practices such as pruning, weeding and fertilizer and pesticide application is considered to be the most effective way to increase production. This is because a greater part of cocoa production is lost through weeds, pests and diseases on the farm (Binam et al., 2008; Dzene, 2010). For these reasons, efficiency has remained a significant topic of research especially in less developed countries where a larger proportion of the farmers are resource-poor (Amos, 2007; Binam et al., 2008; Nkamleu et al., 2010). Several studies (Ogundari et al., 2006; Amos, 2007 and Popoola et al., 2015) have used the single step estimation of stochastic frontier production function to analyse the technical efficiency of cocoa production in the country but there is a paucity of empirical application of stochastic metafrontier-Tobit function on cocoa production in Nigeria.

The meta-frontier approach developed by Battese and Rao (2002), Battese et al., (2004) and O’Donnell et al., (2008) is a useful concept when the aim of the analysis is to compare the efficiency of different groups (e.g., region, states, countries, plant varieties) when there is the suspicion that each group operate under different technologies and therefore their productive frontiers are different. If the production units under analysis make choices from different production possibilities sets then the common approach of estimating a single technology frontier will yield efficiency and productivity estimates that do not accurately measure the capacity of production units to transform inputs into outputs (O'Donnell et al., 2008). The usual methods of dealing with these technology differences risk attributing "technology gaps" between farms to technical inefficiency. This framework has been used extensively in the literature to evaluate the efficiency in agricultural production (e.g., Chen and Song (2008), O'Donnell et al., (2008), Villano et al., (2010), Otieno et al., (2014), Henningsen et al., (2015), Chebil et al., (2016)). The study will therefore adopt the SM-Tobit approach to estimate the technical efficiency and technology gap ratio in cocoa production in Nigeria.

\section{Methodology}

\subsection{Study area}

The study was carried out in three geopolitical zones in Nigeria. Nigeria is made up of six geopolitical zones out of which cocoa is produced in exportable quantities in five geopolitical zones: South West, South South, South East, North Central and North East. Three zones (South West, South South and North Central) representing 60percent of the cocoa producing zones in Nigeria were selected for the study. These three zones were purposively chosen to give the study a nation-wide focus. However, the study was carried out in three States: Ondo State (South West zone), Edo State (South South zone) and Kwara State (North Central zone).

\subsection{Sampling procedure}

The respondents were selected through a multi-stage sampling technique. The first stage involved purposive selection of five out of six geo-political zones where cocoa is commercially grown in Nigeria. In the second stage, stratified sampling technique was used to group the five cocoa producing geopolitical zones into high, medium and low zones. Following NBS, (2012); National Survey on 
Agricultural Exportable Commodities (NSAEC), (2013), the zones are classified as high (South West), medium (South South) and low (South East, North Central and North East). The third stage involved purposive selection of one state from each of the high, medium and low zones. These are Ondo (high), Edo (medium) and Kwara (low). In the fourth stage, two agricultural zones were selected from each state through random sampling technique. The fifth stage involved the use of simple random sampling technique to select one Local Government Area (LGA) from each agricultural zone using the list of LGAs available in the agricultural zone as sampling frame. In the sixth stage, five villages were randomly selected from each of the LGAs giving a total of 30 villages. The basis of selection was the dominance of cocoa production in these villages. Finally, in the seventh stage, a simple random sampling procedure was used in choosing 13 cocoa farmers from each of the 30 villages giving a total of 390 farmers for interview using the list of cocoa farmers from the agricultural zones as the sample frame. However, a total of 350 questionnaires (110 for Kwara state; 118 for Edo state and 122 for Ondo state) were used for analyses as others were discarded due to incomplete information.

The study was based on primary data collected by personal administration of questionnaire/interview schedule on individuals that are involved in cocoa production in the study areas. The respondents were asked questions germane to the achievement of the research objectives.

\subsection{Analytical framework}

The stochastic metafrontier-Tobit (SM-Tobit) method was used to assess the technical efficiency and its determinants by states in the study area. The use of a stochastic metafrontier-Tobit function is a methodological improvement over the one-step stochastic frontier approach (SFA) because the metafrontier framework accounts for technology gaps and allows comparison of TEs across heterogeneous groups such as production systems (Battese and Rao, 2002; Villano et al., 2010). Despite the wide number of empirical studies on technical efficiency, and the proliferation of methodological frontier studies, there is dearth of application of empirical study using stochastic metafrontier-Tobit function on cocoa production in $\mathrm{Ni}$ geria. Estimation of the SM-Tobit involves three stages. First, the SFA (Aigner et al, 1977; Meeusen and van den Broeck, 1977) was used to investigate TEs across the production systems. In the second stage, a metafrontier (Battese and Rao, 2002) was estimated to adjust the TE scores from SFA, taking into account any technology differences. Finally, a Tobit model was applied to assess variations in the TE scores obtained from the metafrontier estimation.
The parameters of the stochastic frontiers for the three regions were estimated using the Cobb-Douglas (CD) specification where all the descriptive variables were included in the Z-vector as possible determinants of inefficiency. Thus, the model is specified as:

$$
\begin{aligned}
& \ln Q_{n(k)}=\beta_{0(k)}+\sum_{i=1}^{5} \beta_{i(k)} \ln X_{n i(k)}-Z \delta_{n(k)}+ \\
& V_{n(k)}-U_{n(k)}
\end{aligned}
$$

Where $\mathrm{Qn}(\mathrm{k})$ is the yield of cocoa in $\mathrm{kg} / \mathrm{ha}$; Xni represents a vector of inputs where $\mathrm{Xn}_{1}$ is area cultivated to cocoa in hectares, $\mathrm{Xn}_{2}$ is hired labour use (workdays/ ha), $\mathrm{Xn}_{3}$ is family labour use (workdays/ha), $\mathrm{Xn}_{4}$ is age of farm (years), while $\mathrm{Xn}_{5}$ is fertilizer ( $\mathrm{kg} / \mathrm{ha}$ ) and $\mathrm{Xn}_{6}$ is pesticide use (gramme a.i/ha)); v represents statistical noise, and $\mathrm{u}$ denotes technical inefficiency. $\mathrm{Z}$ denotes the vector of socio-demographic and other independent variables assumed to influence efficiency where $Z_{1}$ is sex of farmer (1-male, 0 - female), $Z_{2}$ is age (years), $Z_{3}$ is educational level (years), $Z_{4}$ is household size (No of people), $Z_{5}$ is extension visit (dummy), $Z_{6}$ is cocoa variety (dummy) and $Z_{7}$ is health hazard; is a vector of inefficiency parameters to be estimated; $v$ represents statistical noise, and $\mathrm{u}$ denotes technical inefficiency.

The next stage involved the estimation of a pooled stochastic frontier and the possible determinants of inefficiency and the metafrontier-Tobit model specified as

$$
\begin{aligned}
& \theta^{k^{*}}=Z \delta+e \\
& \theta^{k}=\left\{\left(0 \text { if } \theta^{k^{*}}<0\right) ;\left(\theta^{k^{*}} \text { if } 0<\theta^{k^{*}}<1\right) ;\left(\text { if } \theta^{k^{*}}>1\right)\right\}
\end{aligned}
$$

where and $\theta^{\mathrm{k}}$ are the latent and observed values of the metafrontier TE scores, respectively; $\mathrm{Z}$ denotes the vector of socio-demographic and other independent variables assumed to influence efficiency where $Z_{1}$ is sex of farmer (1-male, 0 - female), $Z_{2}$ is age (years), $Z_{3}$ is educational level (years), $Z_{4}$ is household size (No of people), $Z_{5}$ is extension visit (dummy), $Z_{6}$ is cocoa variety (dummy) and $\mathrm{Z}_{7}$ is health hazardand $\mathrm{e}$ is the random term.

The parameters of the stochastic frontiers were obtained by using FRONTIER 4.1 software (Coelli, 1996). The linear programming, to estimate metafrontier and bootstrapping of standard errors were undertaken in SHAZAM version 10 (Whistler et al., 2007), while STATA version 11 (StataCorp, 2009) was used for the Tobit analysis.

\section{Results and Discussion}

\subsection{Summary statistics of variables included in the SFA and MF Model}

The summary statistics in Table 1 display the mean values of the explanatory variables in the model. Edo State 
had the highest mean amount of cocoa output and pesticide usage over the specified period. Between the other two states, Ondo State earned more in terms of their cocoa output and pesticide usage when compared to Kwara State. Ondo State had the highest farm size, employed the highest number of labour and had the oldest farms while Edo State had the youngest farms among the study areas. Kwara State had the least farm size but had the highest usage of fertilizer inputs when compared with Edo and Ondo States.

From the pooled data, an average cocoa farmer has 6.82 hectares' land area cultivated to cocoa employs 5 agricultural labour that works for 205 mandays and 3 family labour that works for 81 mandays, applies $1,016 \mathrm{~kg}$ of chemical fertilizer and 8776 gram active ingredients of pesticide. This generates $1,219 \mathrm{~kg}$ of cocoa output in the specified period. This reflects that cocoa production is being practiced on a medium scale in the study area.

\subsection{Production function estimates by states and determinants of technical efficiency of cocoa production across the states}

The null hypothesis that there are no technical efficiency effects in the models was tested using a likelihood ratio (LR) test of one-sided error. The result from the hypothesis suggests that the inefficiency effects were present in all the models and so the decision to preclude them was rejected as the LR test statistics of 78.22, 72.03, 85.60 and 56.19 for Kwara, Edo, Ondo States and the pooled data respectively, are all greater than the critical LR chi-square value 30.60 .

The single-stage maximum likelihood procedure of the FRONTIER 4.1 program (Coelli 1996) was used to estimate the parameters of the stochastic frontiers (maxi- mum attainable output) for each state (Table 2) and for the pooled data (Table 5). The study reveals that the gamma estimate which measures the deviation of the observed output from the frontier output is estimated to be 0.97 , 0.89, 0.92 and 0.60 for Kwara, Edo, Ondo States and the pooled data, respectively. This implies that in all the models, most of the deviations in the total output are largely as a result of the inefficiency in input use and other farm practices, whilst the random factors which may include unfavourable weather conditions, pest and disease infestation, statistical errors in data measurement and the model specification contribute $3 \%, 11 \%, 8 \%$ and $40 \%$, in Kwara, Edo, Ondo and the pooled data respectively to the deviations of the actual output from the frontier output.

\section{Kwara State}

Estimate of the parameters of the stochastic frontier model in Table 2 reveals that the coefficients of farm size $(\mathrm{p}<0.01)$ and fertilizer $(\mathrm{p}<0.01)$ were positive and significant. This implies that an increase in the area cultivated to cocoa production and fertilizer usage would increase cocoa output in the state. Family labour $(\mathrm{p}<0.05)$ and age of trees $(p<0.05)$ had negative significant relationship with cocoa output in Kwara State. This implies that a percentage increase in number of family labour used and age of trees will reduce cocoa output by $0.080 \mathrm{~kg}$ and $0.130 \mathrm{~kg}$ respectively. The negative effect of the tree age implies that as most of the cocoa trees increase in age, their output falls. The result supports the findings of Gray (2001) and Onumah et al., (2013) that the negative influence of cocoa tree age is a signal for producers to replace old trees with new ones.

The result of the inefficiency model reveals that inefficiency in cocoa production in the state decreases with sex

Table 1. Summary Statistics of Variables Included in the SFA and MF Model

\begin{tabular}{|c|c|c|c|c|c|c|c|c|}
\hline & & $\begin{array}{l}\text { Cocoa } \\
\text { output }\end{array}$ & $\begin{array}{c}\text { Farm size } \\
\text { (ha) }\end{array}$ & $\begin{array}{l}\text { Hired labour } \\
\quad \text { (md.) }\end{array}$ & $\begin{array}{c}\text { Family } \\
\text { labour } \\
\text { (md.) }\end{array}$ & $\begin{array}{c}\text { Age of } \\
\text { Trees } \\
\text { (years) }\end{array}$ & $\begin{array}{c}\text { Fertilizer } \\
(\mathrm{kg})\end{array}$ & $\begin{array}{l}\text { Pesticide } \\
\text { (gm./ai./ha) }\end{array}$ \\
\hline \multirow{2}{*}{ Kwara } & Mean & 1112.00 & 3.62 & 108.6 & 75.9 & 35.42 & 1234.0 & 5212.8 \\
\hline & Std. Deviation & 393.03 & 0.33 & 52.03 & 22.13 & 7.10 & 389.80 & 833.62 \\
\hline \multirow{2}{*}{ Edo } & Mean & 1294.30 & 6.17 & 185.1 & 92.6 & 23.70 & 734.9 & 10130.8 \\
\hline & Std. Deviation & 1508.99 & 1.30 & 48.31 & 35.75 & 8.16 & 202.86 & 754.62 \\
\hline \multirow{2}{*}{ Ondo } & Mean & 1250.82 & 10.13 & 303.9 & 54.6 & 37.19 & 987.4 & 8884.8. \\
\hline & Std. Deviation & 1255.73 & 8.78 & 94.88 & 13.48 & 12.04 & 257.38 & 798.27 \\
\hline \multirow{2}{*}{ Pooled } & Mean & 1219.04 & 6.82 & 204.6 & 81.84 & 32.79 & 1016.2 & 8775.9 \\
\hline & Std. Deviation & 1154.66 & 5.21 & 73.52 & 18.72 & 10.10 & 475.25 & 935.98 \\
\hline
\end{tabular}

Source: Authors' compilation 
Table 2. Production Function Estimates and Determinants of Technical Efficiency of Cocoa Production across the States

\begin{tabular}{|c|c|c|c|c|}
\hline Variable & Coefficient & Kwara State & Edo State & Ondo State \\
\hline Constant & $\beta_{0}$ & $7.191 * * *(11.93)$ & $4.761 * * *(5.63)$ & $5.810 * * *(16.7)$ \\
\hline ln Farm size & $\beta_{1}$ & $1.143 * * *(9.281)$ & $0.327 * * *(3.075)$ & $0.012 * * *(10.29)$ \\
\hline In Hired Labour & $\beta_{2}$ & $0.094(1.486)$ & $1.156(0.983)$ & $-0.04 * * *(-2.74)$ \\
\hline In Family Labour & $\beta_{3}$ & $-0.080 * *(-2.303)$ & $-0.141(-1.541)$ & $0.670(1.497)$ \\
\hline ln Tree Age & $\beta_{4}$ & $-0.130 * *(-2.044)$ & $0.171 * * *(3.041)$ & $-0.052 * *(-2.06)$ \\
\hline ln Fertilizer & $\beta_{5}$ & $0.013 * * *(3.372)$ & $0.032 * * *(2.957)$ & $0.139 * * *(4.852)$ \\
\hline ln Pesticide & $\beta_{6}$ & $-0.067(-1.048)$ & $0.134 * *(2.257)$ & $0.014 * * *(4.041)$ \\
\hline \multicolumn{5}{|l|}{ Inefficiency Effects } \\
\hline Constant & $\delta_{0}$ & $-0.293(-0.401)$ & $0.668(0.839)$ & $2.799(7.510)$ \\
\hline Sex & $\delta_{1}$ & $-0.292 * *(-2.021)$ & $-0.218(-1.098)$ & $0.061(0.105)$ \\
\hline Age & $\delta_{2}$ & $0.020 * * *(3.355)$ & $0.004 * *(2.497)$ & $-0.11 * * *(-2.59)$ \\
\hline Education & $\delta_{3}$ & $-0.003(-0.538)$ & $-0.024(-0.738)$ & $0.106 * *(2.162)$ \\
\hline Household Size & $\delta_{4}$ & $0.021(0.115)$ & $-0.315(-1.197)$ & $-0.244(-0.504)$ \\
\hline Extension Visits & $\delta_{5}$ & $0.015(0.221)$ & $-0.006^{* *}(-2.253)$ & $-0.87 * * *(-7.79)$ \\
\hline Variety & $\delta_{6}$ & $0.131(0.432)$ & $-0.071 * *(-2.251)$ & $0.057(0.620)$ \\
\hline Sigma-squared & $\sigma^{2}$ & $0.072 * * *(4.025)$ & $0.311 * * *(5.913)$ & $0.622 * * *(2.560)$ \\
\hline Gamma & $\gamma$ & $0.97(20.592)$ & $0.89(9.150)$ & $0.92(13.558)$ \\
\hline
\end{tabular}

$* * *=$ significant at $1 \%\left(\propto_{0.01}\right) * *=$ significant at $5 \%\left(\propto_{0.05}\right)$ Figures in parenthesis are $t$-values

of the farmers as it was negative and significant at $5 \%$ alpha level. This implies that male farmers were more technically efficient that their female counterpart in the state. This result confirms the findings of Onumah et al., (2013) who submitted that female farmers were unlikely to be chanced to attend the agricultural extension meetings because of the household chores.

Age of the cocoa farmers was positive and significant at $1 \%$ alpha level. This implies that inefficiency increases with the age of the farmers implying that younger farmers were more technically efficient than the older ones. The reason for this is that the younger farmers are more active and receptive of innovation than the older ones. Similar result was reported by Mariano et al., (2010). The estimate of the sigma-square is significantly different from zero at one percent level, attesting to the goodness of fit of the model.

\section{Edo State}

The study reveals that farm size $(\mathrm{p}<0.01)$, age of trees $(p<0.01)$, fertilizer $(p<0.01)$ and pesticide $(p<0.05)$ had a positive influence on cocoa output in Edo state. This indicates that a $1 \%$ increase in the usage of these inputs will increase cocoa output by $0.33 \mathrm{~kg}, 0.17 \mathrm{~kg}, 0.03 \mathrm{~kg}$ and $0.13 \mathrm{~kg}$ respectively. The positive and significant in- fluence of age of trees in the state implies that the cocoa trees in the state were still young and within their productive years.

The result of the inefficiency model for the state reveals that age of the cocoa farmers increases technical inefficiency at $5 \%$ alpha level. This implies that the younger farmers were more technically efficient than the older ones. Ajayi and Adeyemi (2016) reported that older farmers are generally risks averse and attached to traditional ways of farming leading to inefficiency in their farm operations. Extension visits $(\mathrm{p}<0.05)$ reduce inefficiency of cocoa farmers in the state. This implies that cocoa farmers who were visited frequently by the extension agents were more technically efficient than those visited few times. This finding agrees with the findings of Balogun et al., (2011) who reported that extension work is a prerequisite for dissemination and adoption of agricultural innovations for improved efficiency. Variety of cocoa planted $(p<0.05)$ was also found to reduce inefficiency of cocoa production as it was negative and significant at $5 \%$ alpha level. This implies that the cocoa farmers that planted more of hybrid variety were more technically efficient than the farmers that planted the local variety alone. The estimate of the sigma-square for Edo state is also significantly different from zero at one percent level, attesting to the goodness of 
fit of the model.

\section{Ondo State}

Farm size $(\mathrm{p}<0.01)$, fertilizer $(\mathrm{p}<0.01)$ and pesticide $(p<0.01)$ had positive significant influence on cocoa output in Ondo State. This implies than an increase in the usage of these inputs will increase cocoa output in the state. Conversely hired labour $(\mathrm{p}<0.01)$ and age of trees $(\mathrm{p}<0.05)$ had negative significant influence on cocoa production in Ondo State. The negative influence of hired labour implies that a percentage increase in number of people employed to work on cocoa farms in the state would reduce cocoa output by $0.06 \mathrm{~kg}$. This result disagrees with Binam et al., (2008); Nkamleu et al., (2010) and Onumah et al., (2013) that labour increases cocoa output. The negative influence of age of cocoa trees is a pointer to the fact that majority of cocoa trees in the state were old and beyond their productive age leading to reduced efficiency.

The results of the inefficiency model reveal that age of the farmers was negative and significant at $1 \%$ level. This implies that older cocoa farmers were more technically efficient compared to the younger ones. The reason for this according to Onumah et al., (2013) could be that cocoa production is the only occupation engaged in by the older farmers, to which they devote more time and attention compared to the younger farmers who may have other engagements such as trading, artisan activities etc. Extension visits $(\mathrm{p}<0.01)$ was also found to decrease inefficiency in cocoa production in the state. This is an indication that farmers were attentive at the training sessions organised by the extension agents. Onumah et al., (2013) posited that cocoa farmers' production efficiency improves with effective extension visits and supervision.

Contrary to the a priori expectation, educational level $(p<0.05)$ of the farmers had a positive significant relationship with inefficiency in the state. This suggests that highly educated cocoa farmers were less efficient than those with lower level of education. The level of education could denote engagement in cocoa production as secondary education; thereby influencing farmers' technical efficiency. This result is in line with Nyagaka et al., (2010) and Onumah et al., (2013) that formal education may not necessarily improve one's technical efficiency but the level of one's knowledge and education pertaining to the practices of cocoa production matters.

Table 3 demonstrates that cocoa production in Edo State and the pooled data exhibit increasing returns to scale of 1.679 and 1.24 indicating that a percentage increase in all inputs will result in a $1.68 \%$ and $1.24 \%$ increase in the level of output. This implies that these study areas were in stage one of the production process where increases in the level of all inputs used in production results in a more than the proportionate increase in output. This is an indication that there is more room for the states to expand their scale to increase production in the long run, subject to good quality input usage. Kwara State and Ondo State cocoa production, on the contrary, exhibits a decreasing return to scale of 0.973 and 0.719 which imply that a $1 \%$ increase in all inputs used in production will result to a less than proportionate increase in output.

Table 3. Production Elasticities and Return to Scale in the Study Areas

\begin{tabular}{ccccc}
\hline Variable & Kwara State & Edo State & Ondo State & Pooled \\
\hline Farm Size & 1.143 & 0.327 & 0.012 & 0.688 \\
Hired Labour & 0.094 & 1.156 & -0.064 & -0.025 \\
Family Labour & -0.080 & -0.141 & 0.670 & 0.064 \\
Age of farm & -0.130 & 0.171 & -0.052 & 0.411 \\
Fertilizer & 0.013 & 0.032 & 0.139 & 0.047 \\
Pesticide & -0.067 & 0.134 & 0.014 & 0.055 \\
RTS & 0.973 & 1.679 & 0.719 & 1.24 \\
\hline
\end{tabular}

\subsection{Production function estimates and determinants of technical efficiency of the pooled and metafrontier data}

Results from the pooled stochastic and metafrontier data are presented in Table 4.

\section{Pooled data}

Results from the pooled data reveal that farm size $(p<0.01)$, fertilizer $(p<0.01)$ and pesticide $(p<0.01)$ had positive significant influence on cocoa output in all the study areas. This implies that a percentage increase in the use of these inputs would increase cocoa output by $9.17 \mathrm{~kg}$, $6.75 \mathrm{~kg}$ and $2.99 \mathrm{~kg}$ respectively. Age of trees $(\mathrm{p}<0.05)$ however, had negative significant influence on cocoa output in the study areas. This implies that a year increase in the age of cocoa trees will reduce cocoa output by $2.11 \mathrm{~kg}$ in all the study areas. This result is in consonance with Onumah et al., (2013) that technical efficiency of cocoa production reduces with age of the cocoa trees.

The results of the inefficiency model for the pooled data reveal that sex $(p<0.01)$, age $(p<0.05)$ and household size $(p<0.05)$ reduce inefficiency of cocoa farmers in the study areas. The inverse relationship of sex with inefficiency of cocoa farmers implies that the female cocoa farmers were more technically inefficient when compared to their male counterparts' in the study areas. This result is in consonance with Binam et al., (2008) and Onumah et al., (2013). The negative influence of age implies that 
younger farmers were more technically inefficient than older farmers in the study area. This result disagrees with Mariano et al., (2010) who reported that older farmers produce with more inefficiencies compared to younger farmers. Household size of the cocoa farmers also had an indirect relationship with inefficiency. This indicates that cocoa farmers with large household size were more technically efficient than the small household sized cocoa farmers in the study area. This could be attributed to possibility of availability of household/family labour input. The estimate of the sigma-square is significantly different from zero at one percent level, attesting to the goodness of fit of the model. This also implies that the frontier model is stochastic (rather than deterministic).

Moreover, the estimated value of gamma is significantly different from zero at $1 \%$, implying that 60 percent of the discrepancies between the observed value of cocoa output and the frontier output can be attributed to factors within the cocoa farmers' control.

\section{Metafrontier model}

After the estimation of the individual SPF's, it is necessary to verify if the three states share the same technology. If the three states share the same production frontier (i.e., no significant difference between the single region frontiers), then there would be no reason for estimating the pooled MF production model. This can be done with a likelihood ratio test (LR). The LR statistic is given by

$$
\lambda=2 \times\left[L\left(H_{A}\right)-L\left(H_{O}\right)\right]
$$

where $\mathrm{L}(\mathrm{H} 0)$ is the value of the log likelihood function for a stochastic frontier estimated by pooling the data for all states and L(HA) is the sum of the values of the log-likelihood functions from the individual SPF's. The analysis showed that the value of the LR statistic is 157.62 which is highly significant and implies that the null hypothesis was rejected. The result suggests that the three regional stochastic frontiers for cocoa production in the study areas were not the same, implying that production structure and technology adoption were different among the three states. Hence, the meta-frontier technique is the appropriate estimation approach for this study and that any efficiency comparison among these states should be undertaken with respect to the meta-frontier instead of the pooled stochastic frontier. Similar results have been obtained by Battese et al., (2004); Binam et al., (2008); Mariano et al., (2010); Moreira and Bravo-Ureta (2010); Onumah et al., (2013) among others.

The metafrontier result indicates that an increase in the

Table 4. Production Function Estimates and Determinants of Technical Efficiency of the Pooled and metafrontier Data

\begin{tabular}{|c|c|c|c|}
\hline Variable & Coefficient & Pooled (SFA) & Metafrontier-Tobit \\
\hline Constant & $\beta_{0}$ & $5.789 * * *(20.207)$ & $1.038 * * *(3.963)$ \\
\hline Farm size & $\beta_{1}$ & $0.688 * * *(9.171)$ & $0.085^{* *}(2.180)$ \\
\hline Hired Labour & $\beta_{2}$ & $-0.025(-1.597)$ & $-0.142(-1.413)$ \\
\hline Family Labour & $\beta_{3}$ & $0.064(1.167)$ & $-0.421 * * *(-5.034)$ \\
\hline Age of Trees & $\beta_{4}$ & $-0.411 * *(-2.110)$ & $-0.330 * * *(-2.931)$ \\
\hline Fertilizer & $\mathrm{B}_{5}$ & $0.047 * * *(6.749)$ & $0.606 * * *(3.956)$ \\
\hline Pesticide & $\mathrm{B}_{6}$ & $0.055^{* * *}(2.992)$ & $0.333 * * *(5.590)$ \\
\hline \multicolumn{4}{|l|}{ Inefficiency Effects } \\
\hline Constant & $\delta_{0}$ & $0.050 * *(-2.298)$ & $1.038 * * *(5.963)$ \\
\hline Sex & $\delta_{1}$ & $-0.065 * * *(-3.251)$ & $-0.285(-0.662)$ \\
\hline Age & $\delta_{2}$ & $-0.115 * *(-2.279)$ & $-0.004 * * *(-2.555)$ \\
\hline Education & $\delta_{3}$ & $-0.155(-0.624)$ & $-0.003(-0.222)$ \\
\hline Household Size & $\delta_{4}$ & $-0.941 * *(-2.122)$ & $0.843 * * *(3.671)$ \\
\hline Extension Contact & $\delta_{5}$ & $0.018(0.785)$ & $0.045^{* * *}(3.423)$ \\
\hline Variety & $\delta_{6}$ & $0.192(1.489)$ & $-1.014 * *(-2.306)$ \\
\hline Sigma-squared & $\sigma^{2}$ & $0.511 * * *(3.554)$ & \\
\hline Gamma & $\gamma$ & $0.602 * * *(4.900)$ & \\
\hline
\end{tabular}

$* * *=$ significant at $1 \%\left(\propto_{0.01}\right) * *=$ significant at $5 \%\left(\propto_{0.05}\right) *=$ significant at $10 \%\left(\propto_{0.10}\right)$ Figures in parenthesis are $t$-values 
area of land cultivated to cocoa ( $<<0.05)$, increase in the use of fertilizer $(p<0.01)$ and Pesticide $(p<0.01)$ would lead to significant improvement in cocoa output while the use of more family labour $(\mathrm{p}<0.01)$ and increase in the age of cocoa trees would reduce cocoa output by $5.03 \mathrm{~kg}$ and $2.93 \mathrm{~kg}$ respectively. These results except the result on family labour agree with the findings of Binam et al., (2008), Nkamleu et al., (2010) and Onumah et al., (2013).

It should be noted that in stochastic frontier estimation, the parameter for inefficiency level usually enters the model as the dependent variable in the inefficiency effects component of the model. This, therefore, means that a negative sign of the coefficient of a variable in the $\mathrm{Z}$-vector implies that the corresponding variable would reduce inefficiency (or increase efficiency). On the contrary, a positive sign of the coefficient of a $\mathrm{Z}$-variable is interpreted as potentially having a negative influence on efficiency (Brummer and Loy, 2000; Coelli et al., 2005; Otieno et al., 2014; Bahta et al., 2015). As indicated in Chen and Song (2008), a straightforward interpretation of regression parameters is available from the two-stage Tobit estimation since the dependent variable used in the subsequent Tobit model is the technical efficiency score obtained from optimization in the metafrontier estimation. Therefore, a positive value on a coefficient in the metafrontier-Tobit model infers that increases in the associated variable would increase efficiency (Wooldridge, 2002). The observed statistical differences in cocoa production among the study areas suggests, as indicated by Battese et al., (2004), Otieno et al., (2014), and Bahta et al., (2015) that the pooled stochastic frontier is inappropriate for policy application and are only presented for completeness of the analysis. Therefore, subsequent discussion focuses on the variables that are significant in the metafrontier-Tobit model.

Variety of cocoa planted and frequency of extension visits were found to be significant in the metafrontier-Tobit model, but not in the pooled stochastic frontier, while sex was significant in the pooled stochastic frontier but not significant in the metafrontier-Tobit model.

The result of the metafrontier-Tobit shows that age of the cocoa farmers increases inefficiency as the coefficient of age $(\mathrm{p}<0.01)$ of the cocoa farmers was negative and statistically significant. This implies that younger cocoa farmers were more efficient than older farmers in the study areas. The reason for this is that younger farmers are more educated, exposed, knowledgeable, receptive of innovations and willing to take risks more than the aged farmers. Aminu and Hassan (2016) reported that older farmers are more risk averse and are therefore, reluctant to adopting innovation. This result is consistent with Mari- ano et al., (2010) that older farmers produce with more inefficiencies compared to younger farmers.

Variety $(p<0.05)$ of the cocoa planted also had negative significant relationship with inefficiency of cocoa farmers in the study area. These means that these variables increase inefficiency of cocoa farmers in the study areas. Variety of cocoa implies that farmers who planted the local variety were less technically efficient than farmers who planted the hybrid variety.

Conversely, household size $(\mathrm{p}<0.01)$ and extension contact $(p<0.01)$ had a direct relationship with inefficiency under the metafrontier-Tobit model. These imply large household size and frequents visits from extension agents increase efficiency of cocoa farmers in the study areas.

Technical Efficiency and Technology Gap Ratio (TGR)

The values of the TGR, TE measures for the SPF and with respect to the MF are summarized in Table 5. The TGR values represent the distance between the meta frontier and the regional efficiency frontier for a given vector of inputs. A higher (lower) TGR value implies a smaller (larger) technology gap between the individual frontier and the MF. A TGR value of $100 \%$ is equivalent to a point where a regional frontier coincides with the MF. The study reveals that the mean technical efficiencies from the stochastic frontier models were estimated to be 0.646, 0.95 and 0.828 for Kwara, Edo and Ondo States respectively. These imply that cocoa production in Kwara, Edo and Ondo States were 35.4\%, 5\% and 17.2\% below their group frontier. Technical efficiency scores from the pooled data ranges from 0.3602 to 1.000 with a mean of 0.8079 indicating that cocoa production in the study areas produces about 81 percent of the potential output given the technology available in the country. This result demonstrates that improving the managerial skills and technical capacity of farmers without adding any input can help increase cocoa output by up to 19 percent. Edo State is relatively the most technically efficient state while Kwara State is the least efficient. Weather conditions, pest and diseases, imperfect competition, financial constraints, lack of improved crop varieties, etc., may cause a farmer not to be operating at optimal level (Nkamleu et al., 2010; Onumah et al., 2013).

Estimates of the technology gap ratios (TGR) reveals that the study areas had a mean potential ratio of 0.795 , 0.880 and 0.854 in Kwara, Edo and Ondo States respectively. The values of the TGRs indicate that if cocoa producers in the three states were technically efficient, they could have increased the output by closing a gap of $20.5 \%, 12 \%$ and $14.6 \%$ respectively. The TGR gap for the mean producer was much smaller in Edo and Ondo States, ranging from $12 \%$ to $14.6 \%$, indicating that the extant 
Research on World Agricultural Economy | Volume 02 | Issue 03 | September 2021

Table 5. Technical Efficiency Scores and Technology Gap Ratios (TGR)

\begin{tabular}{ccccc}
\hline & States & SFA-TE & MF-TE & TGR \\
\hline \multirow{3}{*}{ Kwara } & Mean & 0.6461 & 0.5064 & 0.7947 \\
& Std. Deviation & 0.1141 & 0.0859 & 0.1304 \\
& Minimum & 0.3602 & 0.2964 & 0.4593 \\
& Maximum & 0.9993 & 0.6963 & 0.8804 \\
\multirow{3}{*}{ Edo } & Mean & 0.9495 & 0.8369 & 0.0838 \\
& Std. Deviation & 0.7448 & 0.1086 & 0.6461 \\
& Minimum & 0.6891 & 0.5261 & 0.9970 \\
\hline \multirow{3}{*}{ Ondo } & Maximum & 1.000 & 1.0000 & 0.8541 \\
& Mean & 0.8281 & 0.7125 & 0.1762 \\
& Std. Deviation & 0.0889 & 0.1742 & 0.1787 \\
Pooled & Minimum & 0.5501 & 0.1078 & 1.0000 \\
& Maximum & 1.000 & 0.9258 & 0.8431 \\
& Mean & 0.8079 & 0.6852 & 0.1397 \\
\end{tabular}

technologies in these states were near the possibilities' frontier of the meta-technology. Estimate of the pooled TGR ranges from 0.179 to 1.000 with a mean of 0.843 . This implies that, on the average, the cocoa farmers in the study areas would have to close a gap of about $15.7 \%$ in order for them to be technically efficient. Kwara State had the lowest productivity potential ratio. This suggests that even if all cocoa producers from Kwara State achieved best practice with respect to the technology observed in their state, they will still be lagging behind because the technology in Kwara State lags behind regional technology with a TGR of 0.795 . This implies that even if the mean cocoa producer in kwara State were fully technically efficient (i.e., producing on the national efficiency frontier), he/she would still need to increase output by about 21 percent if he/she adopted the most efficient meta-technology in the state. Nkamleu et al., (2010) obtained a similar result for Cameroon in their study on technology gap and efficiency in cocoa production.

Edo State had the highest technology gap ratios (0.880) when compared with other states, indicating that the technologies in Edo State were closer to the possibilities' frontier of the meta-technology than Kwara and Ondo States. This further implies that if all factors were held constant, the producers in Edo State would reach the maximum potential output for cocoa production in the study areas faster than the other States.

The mean technical efficiency scores for cocoa production in the study areas relative to the meta-frontier are $0.506,0.837$ and 0.712 for Kwara, Edo and Ondo States respectively. This indicates that Edo State is more technically efficient than other states in the study areas. An interesting point to note is the difference between the average technical efficiency scores from the national and the meta frontier models. For example, the average technical efficiency for Kwara relative to the meta technology is $50.6 \%$, while its mean efficiency is quite large with respect to its own national frontier $(64.6 \%)$. The differences between the two efficiency scores confirm the inappropriateness of the technical efficiencies obtained by using the SFA, relative to the technology available for cocoa production in the study areas.

\section{Conclusions and Recommendations}

The cocoa farmers exhibited above average efficiency in cocoa production implying that farmers were knowledgeable about cocoa production techniques. However, the technology gap ratio of Kwara State (which is the lowest) confirms the need for the cocoa farmers in the state to step up technology drive for increased cocoa technical efficiency. Based on the findings from the stochastic and metafrontier analysis, the study recommends that:

1) The intervention to raise technology (to close the gap between the regional frontier curve and the global frontier curve) should be adopted in Kwara State. This could be done by raising and distributing disease resistant and high yielding cocoa seedlings to the farmers. Edo and Ondo States could improve their performance through better management using the available technologies and resources.

2) Since the cocoa farmers in the study areas are not realizing their full production potential, there is a need 
for sustained improvements on performance through enhanced roles by the government in educating farmers and planting of younger trees to replace aging ones, which will significantly raise technical efficiency.

\section{References}

[1] Adegeye S. O. (1998): "An evaluation of food crop farming inside old Cocoa Groves" Nigerian Journal of Agriculture 14(1): 22-28.

[2] Aigner D. J., Lovel, C. A. K., and Schmidt P.J. (1977). Formulation and estimation of Stochastic Production Function Models. Journal of Econometrics 6: 21-37.

[3] Ajayi, F.O. and Adeyemi, A.A. (2016). Factors Influencing the Adoption of Moringa Plant Cultivation Among Farming Households in South-western Nigeria: A Tobit Approach. International Journal of Innovative Food, Nutrition \&Sustainable Agriculture 4(4): 15-24.

[4] Aminu, F.O. and Hassan, T.I. Climate Change and Arable Crop Production: A Case of Epe Local Government Area of Lagos State, Nigeria. In Onigemo, M.A., Bolarinwa, J.B., Godonu, K.G., Jaji, M.F.O., Asafa, A.R. and Okeowo, T.A, (Eds.). Revamping Nigerian Agriculture through Public-Private Sector Synergy. Proceedings of $2^{\text {nd }}$ International Conference of School of Agriculture Lagos State Polytechnic, held at Lagos State Polytechnic, Ikorodu, Lagos State, Nigeria. 18th-21st April, 2016. Pg. 103-112.

[5] Amos, T.T. (2007). An analysis of productivity and technical efficiency of smallholder cocoa farmers in Nigeria. Journal of Social Sciences. 15(2):127-133.

[6] Balogun, O. L., Adeoye, A., Yusuf, S. A., Akinlade, R. J.and Carim-Sanni, A (2011). Production Efficiency of Farmers under National Fadama II Project in Oyo State, Nigeria. International Journal of Agricultural Management and Development, 2(1): 11-24.

[7] Bahta, S., Baker, D., Malope, P. and Katjiuongua, H. (2015). A metafrontier analysis of determinants of technical efficiency in beef farm types: an application to Botswana. 29th International Conference of Agricultural Economists ICAE, Milan, Italy.

[8] Battese, G. E. and Rao, D. S. P. (2002). Technology gap, efficiency, and a stochastic metafrontier function. International Journal of Business and Economics, 1(2):87-93.

[9] Battese, G. E., Rao, D. S. P. and O’Donnell, C. (2004). A meta frontier production function for estimation of technical efficiencies and technology gaps for firms operating under different technologies. Journal of Productivity Analysis, 21(1):91-103.
[10] Bečvářová, V. and Verter, N. (2014). Analysis of Some Drivers of Cocoa Export in Nigeria in the Era of Trade Liberalization. Agris on-line Papers in Economics \& Informatics. 6 (4): 208-218.

[11] Binam J.N., Gockowski J. and Nkamleu G.B. (2008): Technical efficiency and productivity potential of cocoa farmers in West Africa countries. The Developing Economics, 3: 242-263.

[12] Brummer, B., Loy, J.P. (2000). The technical efficiency impact of farm credit programmes: A case study in Northern Germany. Journal of Agricultural Economics, 51(3), 405-418.

[13] Cadoni P. (2013). Analysis of incentives and disincentives for cocoa in Nigeria. Technical notes series, MAFAP, FAO, Rome.

[14] CBN. (2009). Annual Reports and Statistical Bulletin 2008. Abuja: Central Bank of Nigeria.

[15] Chebil1, A., Abdelaziz A. H., Alawia, O. H., Ishtiag A., Izzat, T., Solomon, A. and Ouambi, Y. (2016). Metafrontier Analysis of Technical Efficiency of Wheat Farms in Sudan. Journal of Agricultural Science, 8 (2): 179-186.

[16] Chen, Z. and Song, S. (2008). Efficiency and technology gap in China's agriculture: A regional metafrontier analysis. China Economic Review, 19(2):287296.

[17] Coelli, T.J. (1996). A guide to FRONTIER Version 4.1: A Computer Program for Frontier Production Function Estimation. CEPA Working Paper 96/07. School of Economics, University of New England, Armidale.

[18] Coelli, T., Rao, D. S. P., Battese, G. E. (2005). An Introduction to Efficiency and Productivity Analysis, second edition, Kluwer Academic Publishers, Boston.

[19] Dzene R. (2010): What Drives Efficiency on the Ghanaian Cocoa Farm? Ghana Institute of Management and Public Administration (GIMPA), Accra.

[20] Folayan, J.A., Daramola, G.A., Oguntade, A.E. (2006): Structure and performance evaluation of cocoa marketing institutions in South-Western Nigeria: An economic analysis. Journal of Food, Agriculture and Environment 4(2):123-128.

[21] Gray A. (2001): The World Cocoa Market Outlook. LMC International Ltd., Ghana.

[22] Henningsen, A., Daniel, F. M., Anwar, S. A., Joseph, A. K, and Tomasz, G. C. (2015). A Meta-Frontier Approach for Causal Inference in Productivity Analysis: The Effect of Contract Farming on Sunflower Productivity in Tanzania. Selected Paper prepared for presentation at the 2015 Agricultural \& Applied Eco- 
nomics Association and Western Agricultural Economics Association Annual Meeting, San Francisco, CA, July 26-28.

[23] Mariano J.M., Villano, R., Fleming E. and Acda, R. (2010). Metafrontier analysis of farm-level efficiencies and environmental-technology gaps in Philippine rice farming. In: 54th Annual Conference of the Australian Agricultural and Resource Economics Society (AARES), Adelaide, South Australia, 8-12 February 2010.

[24] Meeusen, W. and Van Den Broeck, J. (1977). Efficiency Estimation from Cobb-Douglas Production Function with Composed Error. International Economic Review, 18 (3): 435-444.

[25] Moreira V.H., Bravo-Ureta B.E. (2010). Technical efficiency and metatechnology ratios for dairy farms in three southern cone countries: a stochastic metafrontier model. Journal of Productivity Analysis, 33: 33-45.

[26] National Survey on Agricultural Exportable commodities (NSAEC) (2013): Collaborative Survey Conducted by National Bureau of Statistics, Central Bank of Nigeria, Federal Ministry of Agriculture \& Rural Development and Federal Ministry of Trade \& Investment. May, 2013.

[27] NBS - National Bureau of Statistics (2012), LSMS: Integrated surveys on Agriculture: General Household Survey Panel, 2010/11.

[28] Nkamleu, G.B., Nyameck, J. and Gockowski, J. (2010). Technology Gap and Efficiency in Cocoa Production in West and Central Africa: Implication for Cocoa Sector Development. Working Papers Series No. 104, Africa Development Bank, Tunis, Tunisia.

[29] Nyagaka D.O., Obare G.A., Omiti J.M., Ngoyo W. (2010). Technical efficiency in resource use: evidence from smallholder Irish potato farmers in Nyandaura North District, Kenya. Africa Journal of Agricultural Research, 5: 1179-1186.

[30] O’Donnell, C.J., Rao, D.S.P. and Battese, G.E. (2008).
Metafrontier frameworks for the study of firm-level efficiencies and technology ratios. Empirical Economics 34(2): 231-255.

[31] Ogundari, K., Ojo, S.O. and Ajibefun, I.A. (2006). Economics of Scale and Cost Efficiency in Small Scale Maize Production: Empirical Evidence from Nigeria. Journal of Social Science, 13(2): 131-136.

[32] Oluyole, K.A., Usman, J.M. Oni, O. A. and Oduwole, O.O. 2013. "Input Use Efficiency of Cocoa Farmers in Ondo State, Nigeria." Journal of Finance and Economics 1(1):8-10.

[33] Onumah, J.A., Onumah, E.E., Al-Hassan, R.M. and Brumme, B. (2013). Meta-frontier analysis of organic and conventional cocoa production in Ghana. $A G$ RIC. ECON. CZECH, 59(6): 271-280.

[34] Otieno, D.J., Hubbard, L. and Ruto, E. (2014). Assessment of technical efficiency and its determinants in beef cattle production in Kenya. Journal of Development and Agricultural Economics, 6(6): 267-278.

[35] Popoola, O.A., Ogunsola, G.O. and Salman, K.K. (2015): Technical Efficiency of Coca Production in Southwest Nigeria. International Journal of Agriculture and Food Research, 4 (4): 1-14.

[36] Taphee, B. G., Musa, Y. H. and Vosanka, I. P. (2015). Economic Efficiency of Cocoa Production in Gashaka Local Government Area, Taraba State, Nigeria. Mediterranean Journal of Social Sciences, 6(1): 570576.

[37] Villano, R., Boshrabadi, H. M. and Fleming, E. (2010). 'When is meta frontier analysis appropriate? An example of varietal differences in Pistachio production in Iran. Journal of Agricultural Science and Technology, 12(4):379-389.

[38] Whistler, D., White, K.J., Bates, D., 2007. SHAZAM econometrics software and user's reference manual version 10. Northwest Econometrics, Ltd., Vancouver, http://shazam.econ.ubc.ca/.

[39] Wooldridge, J. M., 2002. Econometric Analysis of Cross Section and Panel Data, MIT Press, Massachusetts. 